\title{
INTRODUKSI MODEL PERENCANAAN PELATIHAN GRANT WRITING SKILL BAGI TENAGA HARIAN LEPAS - TENAGA BANTU (THL-TB) PENYULUH PERTANIAN KABUPATEN JEMBER
}

\author{
Najmah Faizah \\ Dinas Tanaman Pangan Hortikultura dan Perkebunan Kabupaten Jember \\ J1. Brawijaya No. 71 Jember \\ E-mail: najmahfaizah@gmail.com
}

\begin{abstract}
The developing of agriculture has many supports from both government and non-government institutions, implementing in the form of grants/assistance/loan to farmers. There are many types grants can be accessed by farmers on the condition of submitting proposals. On the other hand, farmers with a majority of low-educated people find it difficult to perform. As a extension agent, the contract officer (THL-TB) of agricultural extension agents have obligation to provide assistance to the farmers. Unfortunately, they have limitation capacity and access to develop self-capacity cause the number THL-TB of agricultural extension agents have limitation experiences. This study has aims to determine the characteristics of THL-TB of agricultural extension agent in Jember Regency and to analyze the introduction of training plan model of grant writing skill for THL-TB agricultural extension agent in Jember Regency. The analysis method is descriptive analysis and training plan model of Goad. The target of training participants are 48 THL-TB agricultural extension agents in Jember Regency who under 40 years old with highest education (D3 and bachelor degree I). Introducing training plans uses the basis of the Pimentel and Franco approache consist of 3 elements, they are pre-implementation, implementation and post-implementation.
\end{abstract}

Keywords: Planning, Training, Agricultural Extension Agent, THL-TB, Writing

\begin{abstract}
Abstrak: Upaya pengembangan pertanian banyak sekali didukung oleh lembaga pemerintah dan non pemerintah, dengan mewujudkannya dalam bentuk grant / bantuan bagi petani. Berbagai macam grant yang tersedia dapat diakses petani dengan syarat pengajuan proposal. Pada sisi lain, petani yang mayoritas berpendidikan rendah sulit untuk melakukannya. Sebagai pendamping petani tenaga THL-TB penyuluh pertanian tentu saja berkewajiban memberikan pendampingan terhadap petani. Namun sayangnya, kapasitas dan akses pengembangan diri yang terbatas menjadikan tenaga THL-TB penyuluh pertanian yang jumlahnya 121 orang juga mengalami keterbatasan. Penelitian ini bertujuan untuk mengetahui karakterisitik THL-TB penyuluh pertanian di Kabupaten Jember serta mengetahui introduksi rencana model pelatihan penulisan usulan grant yang tepat bagi THL-TB penyuluh pertanian di Kabupaten Jember. Metode analisis yang digunakan adalah analisis diskriptif dan introduksi model pelatihan Goad. Rencana sasaran pelatihan hanya diperuntukkan 48 tenaga THL-TB penyuluh pertanian Kabupaten Jember yang memiliki usia dibawah 40 tahun dan berpendidikan tinggi (D3 dan sarjana sarjana). Introduksi rencana pelatihan dengan menggunakan basis pendekatan Pimentel dan Franco yang terdiri atas 3 bagian besar: pra-implementasi, implementasi dan pasca implementasi.
\end{abstract}

Kata kunci: Perencanaan, Pelatihan, Penyuluh, THL-TB, Penulisan 


\section{PENDAHULUAN}

Petani perlu mengembangkan kemampuannya di tengah kondisi persaingan global yang ketat. Kemampuan yang perlu dimiliki petani bukan hanya pada bidang budidaya saja (on farm), namun juga mampu menyediakan input yang efisien (up stream), melakukan pengolahan untuk meningkatkan nilai tambah dan mampu memasarkan untuk memperoleh pendapatan maksimal (down stream) dalam sebuah sistem agribisnis. Adam, et al. (2015) menyatakan bahwa petani di Tanzania masih memerlukan pemahaman terkait dengan jenis penyakit yang menyerang ubi jalar (sektor on farm) serta input usahatani (sektor up strem) yang diperlukan dalam mencegah dan mengatasinya. Lebih lanjut berkaca pada petani di Iran di China, Hashemi et al (2009) dan Guo et al. (2015) juga melaporkan masih perlunya dilakukan pelatihan pada peningkatan kemampuan on farm baik pada sisi budidaya maupun perlindungan tanaman. Perlunya penguatan kemampuan petani di sektor down stream terkait dalam kemampuan pengolahan komoditas kakao beserta kelembagaan yang melingkupinya serta pemasaran dan regulasi/kebijakan pemasaran (Raharto, 2016).

Dalam upaya tersebut maka petani perlu kehadiran agen pendamping yang salah satunya adalah penyuluh. Keberadaan agen penyuluh pertanian sangat penting kehadirannya, tapi Indonesia masih mengalami kekurangan jumlah penyuluh untuk mendampingi petani. Berdasarkan catatat Badan Penyuluhan dan Pengembangan Sumberdaya Manusia Kementerian Pertanian, dari 72.000 desa yang memiliki potensi bidang pertanian hanya terdapat 44.000 orang penyuluh yang terdiri dari 25.000 penyuluh PNS dan 19.000 orang Tenaga Harian Lepas-Tenaga Bantu (THL-BP) penyuluh pertanian. Perhatian pada THL-TB perlu lebih untuk dilakukan. Kehadirannya sangat membantu di tengah terbatasnya penyuluh pertanian dengan status PNS.

Jumlah THL-TB sudah cukup banyak, tapi tingkat pendidikannya beragam, masih memiliki tingkat pendidikan SMA, umur lebih dari 40 tahun serta beberapa keterbatasan akses untuk pengembangan kapasitas. Padahal, kemampuan penyuluh sangat penting dalam memberikan layanan pendampingan petani, baik berstatus PNS maupun THL-TB.
Pendampingan oleh penyuluh ini pada dasarnya adalah untuk memajukan pengetahuan, keterampilan dan sikap petani (Abubakar dan Siregar, 2010; Buadi, et al., 2013).

Sebagaimana dinyatakan bahwa dalam lingkup agribisnis terdapat kebijakan-kebijakan yang melingkupi pada up strem, on farm maupun pada down stream. Salah satu kebijakan yang ada adalah adanya grant atau bantuan baik pendanaan, peralatan maupun manajerial dari instansi pemerintah/ swasta dalam mendorong kapasitas petani baik secara kelompok maupun pribadi petani (Ton, et al., 2015). Hal ini dapat merujuk pada grant yang diberikan terkait sarana prasana serta modal guna peningkatan pemasaran komoditas sayur dan buah buahan di North Carolina (Rozelle, et al., 1998 dan Pitts, et al., 2016).

Bila dikaji lebih lanjut hampir semua grant atau bantuan yang ditawarkan ini, memerlukan pengajuan atau proposal sebagai syarat untuk dipelajari pihak pemberi grant. Penulisan proposal yang tepat menjadi faktor penting keberhasilan grant. Dengan mayoritas tingkat pendidikan petani yang masih rendah maka penyuluh mampu hadir sebagai pendamping petani dalam penyusuan proposal grant ini. Perkembangan informasi dan teknologi yang pesat tentu menuntut pengembangan kapasitas bagi penyuluh utamanya bagi THL-TB terkait hak ini. Hasil penelitian Agunga, et al. (2016) menunjukkan $65,6 \%$ penyuluh menilai kemampuan ini adalah sesuatu yang penting.

Hasil kajian Agunga, et al. (2016) menunjukkan kemampuan menulis proposal pengajuan grant bagi penyuluh pertanian di Kabupaten Malang sebagian besar $(71,1 \%)$ masih sedang dan $19 \%$ masih rendah, atau hanya $9,9 \%$ yang telah baik. Hal ini menjadi tantangan mengingat sebagian besar penyuluh berumur $\geq 50$ tahun (60,3\%), 41-50 tahun (32\%), 36-40 tahun $(7,2 \%)$ dan $\leq 36$ tahun $(4,8 \%)$. Sementara tingkat pendidikan yang dimiliki sebagian besar adalah sarjana muda ke atas tanpa diketahui disiplin ilmunya. Ilmu pemberdayaan atau komunikasi diperlukan dalam penyuluhan partisipatory. Beban kerja penyuluh yang melebih bebanya (rasio 3,53) juga menjadi tantangan tersendiri.

Petani di Kabupaten Jember diberikan kebebasan kreativitas dalam menyusul proposal grant. Penyuluh memberikan pendampingan 
dengan basis pengetahuan yang diperolehnya secara autodidak atau berdasarkan pemahaman yang telah diperoleh selama masa sekolah/kuliah. Merespon kondisi ini program pelatihan grant writing skill perlu dilakukan untuk meningkatkan kemampuan penyuluh dalam menulis proposal grant yang baik. Kegiatan pelatihan terbukti dapat meningkatkan keterampilan bukan saja pada kemampuan teknis pertanian (Huang, et al., 2015; Dickson, et al., 2016), namun juga pemahaman dan keterampilan dalam non teknis seperti penggunaan web termasuk penulisan proposal grant (Park, et al., 2012).

Tulisan ini bertujuan untuk mengetahui karakterisitik THL-TB penyuluh pertanian di Kabupaten Jember. Informasi ini menjadi penting untuk memetakan sasaran peserta introduksi model pelatihan. Selanjutnya, tulisan ini akan membahas introduksi model pelatihan dalam upaya peningkatan, pemahaman dan keterampilan penulisan usulan grant yang tepat bagi THL-TB penyuluh pertanian di Kabupaten Jember.

\section{METODE PENELITIAN}

Penelitian dilakukan di Kabupaten Jember Propinsi Jawa Timur, dengan pertimbangan bahwa lokasi tersebut merupakan salah satu sentra pertanian pangan. Selain itu setiap tahun terdapat bantuan atau grant yang dapat diakses oleh para petani/ kelompok tani. Data diperoleh dengan metode sensus terhadap seluruh petugas THL-TB penyuluh Pertanian Kabupaten Jember sejumlah 121 orang.

Analisis karakteristik petugas THL-TB penyuluh pertanian dilakukan dengan menggunakan analisis diskriptif. Sementara analisis introduksi model pelatihan digunakan pendekatan Goad (1982). Model yang dikembangkan tersebut memiliki perbedaan pada siklus, namun pada dasarnya memiliki kesamaan terkait dengan perlu adanya identifikasi kebutuhan pelatihan dan diakhiri adanya evaluasi. Model ini terdiri atas beberapa siklus diantaranya adalah: (1)analisis kebutuhan pelatihan; (2)desain pendekatan pelatihan; (3) pengembangan materi pelatihan; (4) pelaksanaan pelatihan; (5)evaluasi dan pemutakhiran pelatihan.

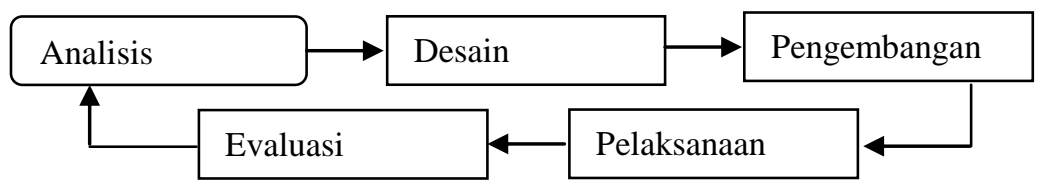

Gambar 1. Model Pelatihan Goad

Tabel 1. Karakteristik THL-TB Penyuluh Pertanian Kabupaten Jember

\begin{tabular}{lrr}
\hline Indikator & Jumlah & Presentase \\
\hline Pendidikan & 57 & \\
$-\quad$ SMA/ Sederajat & 30 & 47,1 \\
- D3 & 34 & 24,8 \\
$-\quad$ Sarjana/ Sederajat & 121 & 28,1 \\
\hline Total & & 100 \\
\hline Masa Kerja & 82 & 67,8 \\
$-\quad 10$ Tahun & 39 & 32,2 \\
$-\quad 11$ Tahun & 121 & 100 \\
\hline Total & & \\
\hline Usia & 15 & 12,4 \\
$-\quad \leq 30$ Tahun & 74 & 61,2 \\
$-\quad 31-40$ Tahun & 29 & 24,0 \\
$-\quad 41-50$ Tahun & 3 & 2,5 \\
- Diatas 50 Tahun & 121 & 100,0 \\
\hline Total
\end{tabular}

Sumber: Dinas Pertanian Tanaman Pangan Jember, 2014 
Metode ini cocok dilakukan pada pendidikan orang dewasa dengan adanya konsep pengembangan. Sebagaimana diungkapkan Westover (2008), dalam pendidikan orang dewasa, suatu teori akan bernilai jika diimplementasikan dan dikembangkan dalam suatu program.

\section{HASIL DAN PEMBAHASAN}

\section{Karakterisitik THL-TB Penyuluh Pertanian di Kabupaten Jember}

Pembahasan terhadap karakterisik THL-TB penyuluh pertanian perlu dilakukan untuk mengetahui basis data kemampuan. Pendidikan, pengalaman yang diindikasikan dengan masa kerja serta umur menjadi indikator penting dalam pemahaman ini.

Pendididikan tenaga THL-TB penyuluh pertanian Kabupaten Jember didominasi oleh tingkatan SMA sederajat $(47,1 \%)$. Selain dari SMA umum juga berasal dari SMK kejuruan bidang pertanian. Terdapat 17 orang yang berasal dari pendidikan SMK pertanian dan selebihnya dari SMA umum. Peringkat kedua diikuti oleh tenaga THL-TB yang memiliki pendidikan sarjana yaitu sebanyak $28,1 \%$. Bidang strata yang digeluti adalah bidang rumpun pertanian, seperti agroekoteknologi, teknologi pertanian maupun agribisnis/sosial ekonomi pertanian. Sementara untuk tenaga THL-TB yang memiliki tingkat pendidikan D3 sebanyak $24,8 \%$. Serupa dengan tenaga THLTB yang memiliki pendidikan sarjana, untuk pendidikan D3 dari para THL-TB ini juga berasal dari jurusan beragam dalam bidang rumpun ilmu pertanian.

Perekrutan tenaga THL-TB Kabupaten Jember ini dilakukan dua kali yaitu pada tahun 2007 dan tahun 2008. Sebagian besar merupakan hasil rekruitmen tahun 2008 $(67,8 \%)$ dan sisanya $32,2 \%$ merupakan hasil rekrutmen 2007. Hal ini mengindikasikan bahwa sebagian besar tenaga THL-TB memiliki masa kerja selama 10 tahun.

Usia para tenaga THL-TB penyuluh pertanian di Kabupaten Jember sangat beragam. Sebagian besar berada pada rentang usia yang potensial dalam pengembangan akademis yaitu pada rentang usia 31-40 tahun $(61,2 \%)$. Selanjutnya disusul oleh kelompok umur pada rentang 41-50 tahun (24\%), umur dibawah 30 tahun $(12,4 \%)$ dan terakhir kelompok umur diatas 50 tahun $(2,5 \%)$.

Jika analisis dilanjutkan dengan tabulasi silang, maka dapat diperoleh bahwa tenaga THL-TB penyuluh pertanian yang berada di bawah usia 40 tahun dan memiliki pendidikan tinggi (D3 dan sarjana) terdapat 48 orang (40\%). Pengelompokan ini menjadi penting mengingat usia rentang usia dibawah 40 tahun adalah usia optimal dalam menerima materi bersifat akademis. Sementara itu pemilihan pada pendidikan tinggi dikarenakan tingkat pendidikan tersebut telah pernah terlatih membuat laporan penelitian ilmiah sebagai tugas akhirnya.

\section{Model Pelatihan Peningkatan Pemahaman Dan Keterampilan Penulisan Usulan Grant Rencana Pelatihan}

Rencana program pelatihan harus dilakukan menyeluruh, mulai awal hingga akhir. Merujuk Pimentel dan Franco (1991), perencanaan pelatihan terbagi 3 bagian besar, yaitu praimplementasi, implementasi dan pasca implementasi. Perencanaan pertama, kegiatan pra-implementasi terbagi atas konseptualisasi (terkait konten materi yang akan diberikan) dan mobilisasi (terkait rencana kerja panitia pelatihan). Perencanaan pra-implementasi dimulai dari analisis kebutuhan pelatihan, penyusunan desain dan pengembangan materi pelatihan dan metodologi. Perencanaan kedua terkait pelaksanaan pelatihan, dimulai dari bagaimana memberikan pandangan terhadap topik umum pelatihan yang memotivasi dan menyenangkan (unfreezing), kemudian penyampaian materi sesuai topik pelatihan, melakukan integrasi antar topik dan selanjutnya mengeevaluasi pada tahapan implementasi. Akhirya setelah implementasi kemudian didokumentasikan. Perencanaan ketiga terkait pasca-pelatihan, dimulai mempersiapkan laporan kegiatan, mempresentasikan kepada pihak dinas, melakukan monitoring dan evaluasi seluruh program kegiatan pelatihan, penyelesaian administrasi dan keuangan serta penyelesaian hal lain terkait program pelatihan ini. Perencanaan laporan ini sangat penting sebagai bentuk pertanggung jawaban pelaksanaan pelatihan kepada pihak dinas maupun pemberi dana pelatihan. 

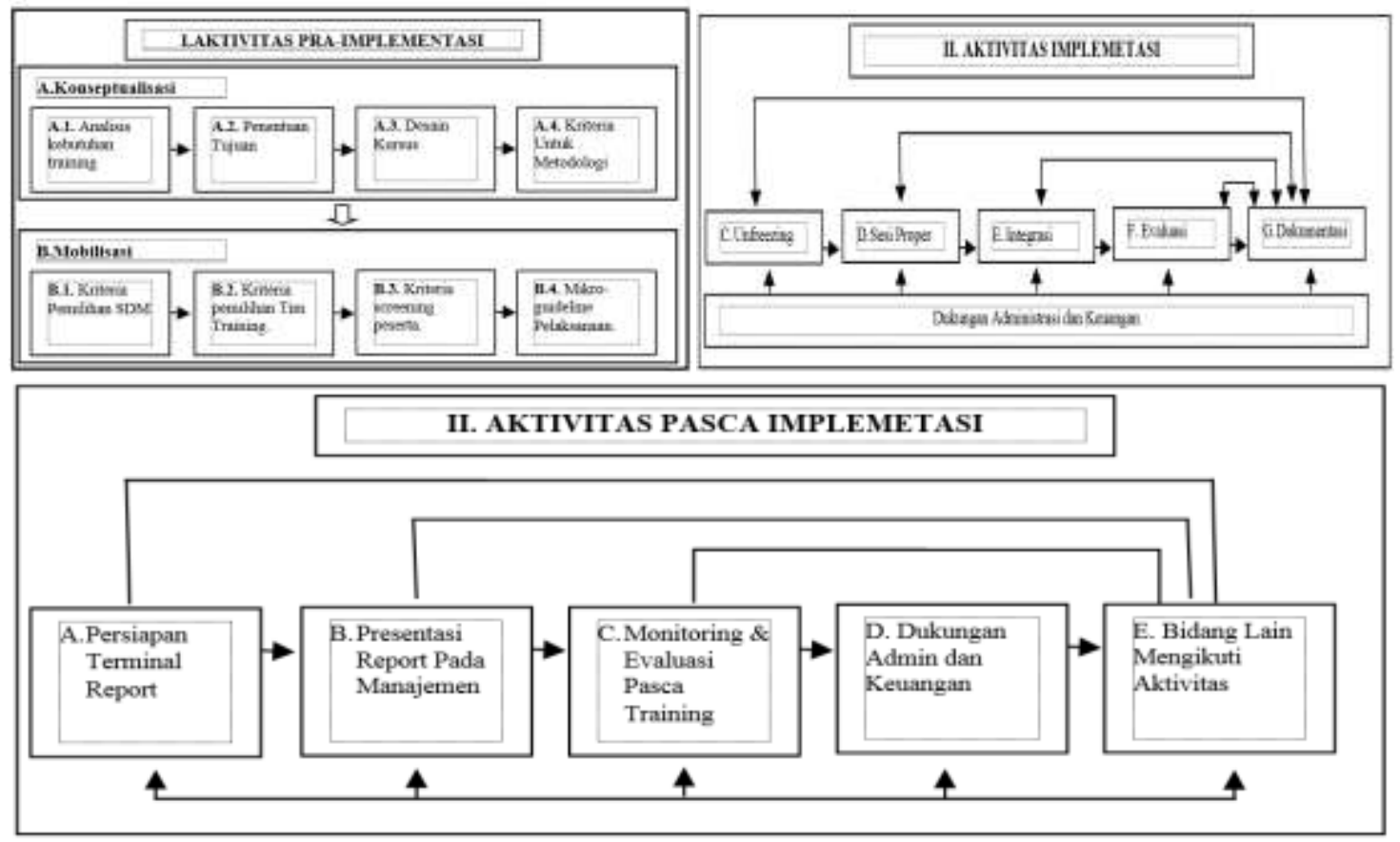

Gambar 2. Bagan Rencana Pelatihan

Tabel 2. Runtututan Rencana Aktivitas Pelatihan

\begin{tabular}{|c|c|c|c|c|c|c|}
\hline \multicolumn{7}{|c|}{ Rencana Aktivitas Pra-Impelementasi (Konseptualisasi) } \\
\hline Analisis kebutuhan & \multicolumn{2}{|l|}{ Tujuan } & \multicolumn{2}{|l|}{ Desain } & \multicolumn{2}{|c|}{ Metodologi } \\
\hline $\begin{array}{l}\text { Meningkatkan } \\
\text { kemampuan penulisan } \\
\text { usulan grant }\end{array}$ & \multicolumn{2}{|c|}{$\begin{array}{lr}\text { Setelah } & \text { Dilakukan } \\
\text { Pelatihan Penulisan Usulan } \\
\text { Grant Selama } & \text { Hari, } \\
\text { Peserta } & \text { Dapat } \\
\text { Mempersiapkan } & \text { Usulan/ } \\
\text { Proposal } & \text { Grant } \\
\text { Pembangunan Pertanian }\end{array}$} & \multicolumn{2}{|l|}{ Gambar 2} & \multicolumn{2}{|c|}{$\begin{array}{l}\text { Ceramah, tanya jawab, } \\
\text { diskusi, pendampingan, } \\
\text { penugasan }\end{array}$} \\
\hline \multicolumn{7}{|c|}{ Rencana Aktivitas Pra-Impelementasi (Mobilisasi) } \\
\hline Kriteria SDM & \multicolumn{2}{|l|}{ Tim Pelatihan } & \multicolumn{2}{|c|}{ Screening Peserta } & \multicolumn{2}{|c|}{ Mikro Guideline } \\
\hline $\begin{array}{l}\text { - Pengalaman } \\
\text { melaksanan } \\
\text { pelatihan } \\
\text { - Memiliki motivasi } \\
\text { - Fixed minus } 30 \text { hari } \\
\text { dari Hari H }\end{array}$ & \multicolumn{2}{|c|}{$\begin{array}{l}\text {-Lembaga perguruan tinggi } \\
\text {-Penyuluh berpengalaman } \\
\text { Grant. } \\
\text {-Fixed minus } 15 \text { hari dari } \\
\text { Hari H }\end{array}$} & \multicolumn{2}{|c|}{$\begin{array}{ll}\text { - } & \text { Umur } \leq 40 \text { tahun } \\
\text { - } & \text { Pendidikan min } \\
& \text { S1 } \\
\text { - } & \text { Fixed minus 20 } \\
& \text { hari dari Hari H }\end{array}$} & \multicolumn{2}{|c|}{$\begin{array}{l}\text { - Menyetorkan usulan grant } \\
\text { - Membawa laptop } \\
\text { - Fixed minus } 3 \text { hari dari } \\
\text { Hari H }\end{array}$} \\
\hline \multicolumn{7}{|c|}{ Rencana Impelementasi } \\
\hline Unfreezing & Sesi proper & \multicolumn{2}{|c|}{ Integrasi } & \multicolumn{2}{|l|}{ Evaluasi } & Dokumentasi \\
\hline $\begin{array}{lr}\text { - Pada saat } & \text { awal } \\
\text { pelatihan } & \\
\text { - Pada } & \text { setiap } \\
\text { pergantian } & \text { sesi/ } \\
\text { menunggu } & \\
\text { persiapan } & \\
\text { pemateri. } & \\
\text { - Diskusi } & \\
\end{array}$ & $\begin{array}{lr}\text {-Kepastian } & \text { kehadiran } \\
\text { pemateri } & \text { yang } \\
\text { ditunjuk. } & \\
\text {-Kesiapan perangkat }\end{array}$ & \multicolumn{2}{|c|}{$\begin{array}{l}\text { Materi disusun } \\
\text { runtut }\end{array}$} & \multicolumn{2}{|c|}{$\begin{array}{l}\text { Dilakukan pada } \\
\text { akhir sesi per hari }\end{array}$} & $\begin{array}{l}\text { Tercatat tiap } \\
\text { akhir per sesi }\end{array}$ \\
\hline
\end{tabular}


Najmah Faizah: Introduksi Model Perencanaan Pelatihan Grant Writing Skill...

\begin{tabular}{|c|c|c|c|c|}
\hline \multicolumn{5}{|c|}{ Rencana Pasca-Impelementasi } \\
\hline Terminal report & Presentasi Report & $\begin{array}{ll}\text { Monev } & \text { Pasca } \\
\text { Pelatihan } & \end{array}$ & Dukungan Admin & $\begin{array}{l}\text { Dukungan Bidang } \\
\text { lain }\end{array}$ \\
\hline $\begin{array}{l}\text { - Dibuat } \\
\text { menyeluruh } \\
\text { - Fixed plus } 5 \text { hari } \\
\text { dari Hari } \mathrm{H}\end{array}$ & $\begin{array}{lr}\text { - } & \text { Persiapan } \\
\text { point } & \text { Power } \\
\text { menyeluruh } & \\
\text { - } \begin{array}{l}\text { Fixed plus } \\
\text { dari Hari H }\end{array} & \end{array}$ & $\begin{array}{l}\text { Hingga } 1 \text { tahun } \\
\text { dari pelaksaaan } \\
\text { pelatihan untuk } \\
\text { meleihat } \\
\text { implementasi }\end{array}$ & 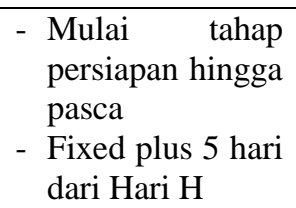 & $\begin{array}{l}\text { - } \text { Mulai tahap } \\
\text { persiapan } \\
\text { hingga pasca } \\
\text { - Fixed plus } 5 \\
\text { hari dari Hari } \mathrm{H}\end{array}$ \\
\hline
\end{tabular}

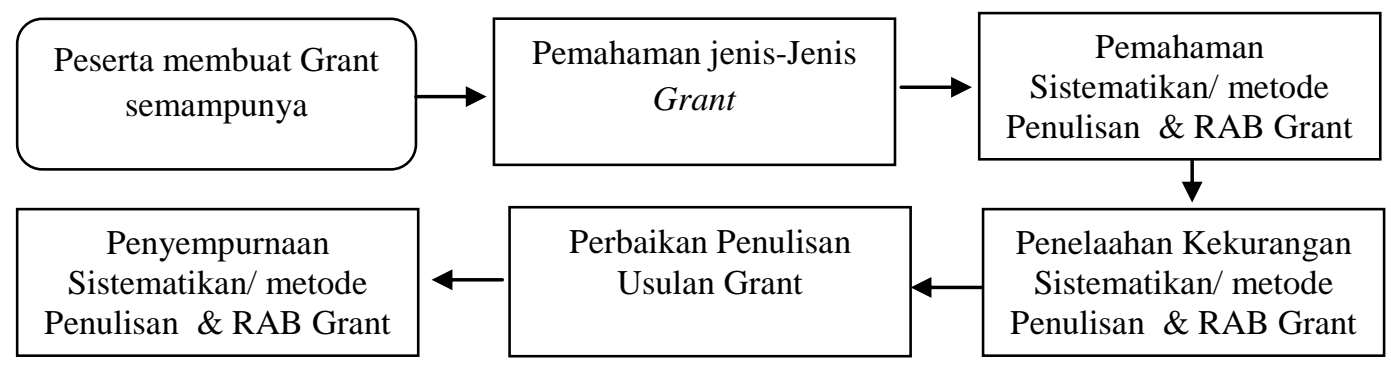

Gambar 3. Bagan Desain Pelatihan

Guna memudahkan hasil rumusan perencanaan pelatihan tersebut dapat dibantu dengan menggunakan tabulasi, sehingga dapat dipahami runtutan rencana aktivitas yang diperlukan pra-implementasi hingga rencana aktivitas yang diperlukan pasca implementasi.

\section{Analisis Model dan Rencana Pelatihan}

Untuk mengetahui kebutuhan pelatihan tentang penulisan usulan grant kepada THL-TB penyuluh pertanian di Kabupaten Jember sebenarnya perlu dilakukan investigasi mendalam baik dengan wawancara maupun dengan kajian hasil penulisan penyuluh. Namun, dikarenakan tidak ada data hasil penulisan proposal grant oleh tenaga THL-TB penyuluh pertanian Kabuaten Jember, maka dapat diasumsikan pelatihan penulisan proposal grant diprioritaskan untuk 48 penyuluh pertanian yang memiliki pendidikan tinggi (D3 dan sarjana). Hal ini dikarenakan tenaga THLTB penyuluh pertanian dengan pendidikan tinggi pernah melakukan penulisan ilmiah dalam tugas akhirnya sehingga diasumsikan telah memahami tata tulis ilmiah secara sistematis serta serta lebih memiliki wawasan luas (Orr dan Mrazek, 2009). Selanjutnya pelatihan juga difokuskan kepada tenaga THLTB penyuluh pertanian dengan umur yang masih relatif muda (maksimal 40 tahun). Sasaran pada tenaga THL-TB penyuluh pertanian berusia muda ini didasarkan pemahaman bahwa dengan usia muda akan memiliki motivasi tinggi dan pemahaman yang lebih baik (Berry, 1993).

Definisi yang akan ditingkatkan dalam pelatihan terkait dengan aspek pengetahuan (kognitif) dan keterampilan menulis (afektif/ skill). Adapun materi yang akan diberikan sesuai dengan sistematika penulisan usualan grant maka mencakup materi: 1)ragam grant nasional yang ditawarkan oleh pemerintah / non pemerintah dan grant internasional; 2)sistematika penulisan usulan grant; 3)penyusunan Rencana anggaran biaya. Materi materi tersebut adalah materi yang sangat diperlukan dalam upaya memberikan pemahaman dan ketrampilan penyuluh dalam menulis usulan grant. Sehingga secara redaksional tujuan pelatihan adalah peserta dapat mempersiapkan usulan/proposal grant Pembangunan Pertanian setelah dilakukan pelatihan penulisan usulan grant selama 2 hari.

\section{Desain Model dan Rencana Pelatihan}

Peserta pelatihan diminta untuk membuat usulan grant sedapat dan semampu yang dilakukan. Selanjutnya pemateri akan memberikan wawasan terkait dengan jenis-jenis grant yang potensial untuk diperoleh. Selanjutnya pemateri memberikan materi tentang metode dan sistimatika penulisan usulan grant berikut RAB yang baik. Pada akhir sesi pada hari-1 peserta akan memperoleh pemahaman tentang jenis-jenis grant serta kelemahan/ kekuarangan atas tulisan yang telah 
dibuat. Selanjutnya peserta diminta memperbaiki tulisan usulan grant sesuai dengan rekomendasi pemateri/fasilitator. Pada hari kedua pemateri/fasilitator mengoreksi dan memberikan masukan tambahan atas perbaikan yang telah dilakukan peserta. Secara sistematis desain pelatihan dapat digambarkan pada skema gambar 3 .
Pengembangan Model dan Rencana Pelatihan Pengembangan pelaksanaan pelatihan akan dapat tertangkap dengan jelas saat dilakukan penelaahan sistematika dan metode penulisan dan RAB grant dari peserta. Berbagai kekurangan akan pemahaman dan keterampilan dari peserta akan dapat tertangkap dengan tepat pada sesi ini. Sehingga peran fasilitator pelatihan akan sangat terlihat dalam menyempurnakan melalui penugasan kepada peserta.

Tabel 3. Pelaksanaan Model dan Rencana Pelatihan Penyusuan Proposal Grant

\begin{tabular}{|c|c|c|c|c|}
\hline $\begin{array}{l}\text { Hari-1 } \\
\text { Jam }\end{array}$ & Materi & Pelaksana & Jenis Pelaksanaan & Fasilitas \\
\hline $07.30-08.00$ & Registrasi & Panitia & $\begin{array}{lr}\text { - Memeriksa } & \text { syarat } \\
\text { utama } & \text { peserta } \\
\text { (pendidikan S1/ umur } \leq \\
40 \text { tahun) } \\
\text { - Menyetoran } \\
\text { grant }\end{array}$ & ATK \\
\hline $08.00-08.30$ & Seremonial & Panitia & $\begin{array}{l}\text { - Penghargaan atas } \\
\text { kehadiran. } \\
\text { - Motivasi dan wawasan } \\
\text { dari pimpinan }\end{array}$ & $\begin{array}{l}\text { - LCD } \\
\text { - Audio visual }\end{array}$ \\
\hline $08.30-08.45$ & Coffee Break & Panitia & Bebas & Konsumsi \\
\hline $08.45-10.45$ & $\begin{array}{l}\text { Pengenalan } \\
\text { jenis-jenis grant }\end{array}$ & Pemateri-1 & $\begin{array}{l}\text { - Ceramah } \\
\text { - Tanya jawab }\end{array}$ & $\begin{array}{l}\text { - LCD } \\
\text { - Audio visual }\end{array}$ \\
\hline $10.45-12.45$ & $\begin{array}{l}\text { Sistematika dan } \\
\text { metode penulisan } \\
\text { usulan grant }\end{array}$ & Pemateri-2 & $\begin{array}{l}\text { - Ceramah } \\
\text { - Tanya jawab }\end{array}$ & $\begin{array}{l}\text { - LCD } \\
\text { - Audio visual }\end{array}$ \\
\hline $12.45-13.30$ & Ishoma & Panitia & Bebas & Konsumsi \\
\hline $13.30-15.30$ & \begin{tabular}{l}
\multicolumn{2}{l}{ Penyusunan } \\
RAB usulan \\
Grant
\end{tabular} & Pemateri-2 & $\begin{array}{l}\text { - Ceramah } \\
\text { - Tanya jawab }\end{array}$ & $\begin{array}{l}\text { - LCD } \\
\text { - Audio visual }\end{array}$ \\
\hline $15.30-16.00$ & $\begin{array}{l}\text { Coffe break / } \\
\text { ibadah }\end{array}$ & Panitia & Bebas & Konsumsi \\
\hline $16.00-17.30$ & $\begin{array}{l}\text { Evaluasi } \\
\text { pelatihan } \\
\text { penelaahan } \\
\text { tulisan usulan } \\
\text { grant }\end{array}$ & Fasilitator & $\begin{array}{ll}\text { - } & \text { Dibagi dalam } \\
\text { kelompok. } & \\
\text { - } & \text { Diskusi }\end{array}$ & $\begin{array}{l}\text { - Papan tulis/ kertas } \\
\text { plano } \\
\text { - Laptop }\end{array}$ \\
\hline 17.30-selesai & $\begin{array}{l}\text { Penugasan } \\
\text { perbaikan }\end{array}$ & Mandiri & Perbaikan secara mandiri & laptop \\
\hline $\begin{array}{l}\text { Hari ke-2 } \\
08.00-10.00\end{array}$ & $\begin{array}{l}\text { Penyempurnaan } \\
\text { Penulisan usulan } \\
\text { Grant }\end{array}$ & Fasilitator & $\begin{array}{l}\text { Penyempurnaan atas } \\
\text { perbaikan yang dilakukan }\end{array}$ & Laptop \\
\hline $10.00-10.15$ & Coffe Break & Panitia & Bebas & Konsumsi \\
\hline $10.15-11.00$ & $\begin{array}{l}\text { Evaluasi } \\
\text { penyempurnaan } \\
\text { penugasan dan } \\
\text { evaluasi Program } \\
\text { pelatihan } 2\end{array}$ & $\begin{array}{ll}\text { Panitia } & + \\
\text { pemateri } & \end{array}$ & Diskusi & $\begin{array}{l}\text { - LCD } \\
\text { - Audio visual }\end{array}$ \\
\hline $11.00-11.30$ & Penutupan & Panitia & $\begin{array}{l}\text { - Award untuk tulisan } \\
\text { terbaik. } \\
\text { - Motivasi }\end{array}$ & $\begin{array}{l}\text { - LCD } \\
\text { - Audio visual }\end{array}$ \\
\hline
\end{tabular}


Pelaksanaan pelatihan sebagaimana rencana dilaksanakan secara efektif selama dua hari. Hari pertama pelatihan akan berfokus pada pengenalan jenis-jenis grant. Setiap grant memiliki karakteristik tersendiri sehingga perlu penyikapan baik secara spesiik. Grant yang berasal dari APBN maupun APBD akan sangat berkaitan dengan keungan negara sehingga nantinya mekanisme yang berlaku baik dalam perencanaan pelatihan, pelaksanaan pelatihan maupun pelaporan akan mengikuti skim kepemerintahan. Berbeda pula jika grant yang berasal dari non-government maka perlu mempelajari dengan cermat petunjuk yang diberikan. Demikian pula perlu diberikan materi sistematika dan metode penulisan. Harapannya proposal grant, dapat dipahami dengan runtut dan jelas. Penyusunan Rencana Anggaran Biaya (RAB) juga perlu diberikan pada hari pertama sebagai bagian penting dari proposal. Isi RAB harus mampu membiayai pelaksanaan pelatihan serta yang paling penting dengan besaran yang masuk akal. Pada hari pertama pelaksanaan pelatihan akan diakhiri dengan penugasan penyusunan proposal grant.

Pada hari kedua akan berfokus pada evaluasi hasil penyusunan proposal grant oleh peserta. Secara terperinci akan diberikan pemanduan dan perbaikan pada proposal grant yang telah dibuat oleh peserta. Saran yang diberikan oleh fasilitator/pemateri akan menjadi rekomendasi yang perlu dijalankan oleh peserta.

\section{Evaluasi Model dan Rencana Pelatihan}

Evaluasi dilakukan sebanyak 2 kali yaitu pada hari pertama dan hari kedua pelatihan. Evaluasi pada hari pertama akan dilihat kemampuan menulis peserta dengan standar hasil materi; andaikan ada pengembangan ide dan kreativitas dari peserta, maka pengembangan itu tidak menabrak koridor penulisan yang yang diarahkan. Evaluasi kedua pada hari pertama mencakup kekurangan materi yang diberikan sesuai dengan harapan peserta pada sesi hari pertama. Sangat dimungkinkan masih terdapat banyak hal yang diinginkan peserta, namun belum tersampaikan. Sehingga nantinya dalam pelaksanaan, fasilitator/pelatih perlu lebih jeli untuk menangkap kebutuhan yang diperlukan oleh peserta.

Evaluasi pertama yang dilakukan pada hari kedua dilakukan dengan melihat hasil perbaikan setelah melaksanakan diskusi pada hari pertama. Peserta harus konsekuen mengerjakan perbaikan yang disarankan oleh fasilitator/pelatih pada hari pertama agar dapat terdeteksi kekurangan yang masih ada. Evaluasi kedua pada hari kedua adalah terkait dengan evaluasi program pelatihan selama dua hari yang telah dilakukan, apakah sesuai dengan ekspektasi peserta serta kesesuaian dengan desain dan rencana yang telah disusun. Jika masih terdapat gap antara rencana dan pelaksanaan maka perlu dicari penyebab dan penyelesaiannya.

\section{Metode Penyelenggaraan Pelatihan}

Terdapat beberapa metode yang perlu diterapkan dalam pelatihan penyusunan proposal grant ini yang terdiri dari metode ceramah, metode tanya jawab, metode diskusi dan metode penugasan. Metode ceramah di ruang pelatihan diberikan pada (1)sesi sambutan/ motivasi oleh pimpinan lembaga yang kompeten (kepala dinas atau pejabat terkait). Sambutan selayaknya bukan hanya sekedar sambutan seremonial namun, namun juga memberikan wawasan dan informasi baru terkait dengan topik bahasan grant serta memberikan motivasi bagi peserta; (2)sesi materi pengenalan jenis grant, Sistematika dan metode penulisan usulan grant dan Penyusunan $\mathrm{RAB}$ usulan grant oleh pemateri yang kompeten.

Metode tanya jawab di ruang pelatihan dilakukan pada setiap sesi materi guna memberikan pemahaman yang lebih. Hal ini untuk menutup atau melengkapi semua materi yang belum dipahami oleh peserta pelatihan. Tanya jawab juga tidak menutup kemungkinan memberikan perbaikan/koreksi atas materi yang disampaikan sehingga nantinya tidak terjadi kesalahan dalam penyusunan proposal grant. Tanya jawab dapat dilakukan secara interupt, atau menyela saat pemaparan ataupun pada akhir sesi, sesuai kesepakatan dengan pemateri.

Metode diskusi di tempat yang disepakati dilakukan pada sesi evaluasi pelatihan/ penelaahan tulisan usulan grant. Evaluasi penyempurnaan penugasan dan evaluasi pelaksanan program pelatihan pada hari kedua. Peserta dibagi menjadi 8 kelompok dimana tiap kelompok terdiri dari 6 orang. 
Tabel 4 Indikator-Indikator Keberhasilan Penyusunan Proposal Grant

\begin{tabular}{|c|c|c|c|c|c|}
\hline No & Item & 1 & 2 & 3 & 4 \\
\hline \multicolumn{6}{|c|}{ Cover } \\
\hline 1 & Daya pikat judul & & & & \\
\hline 2 & Tata letak tulisan & & & & \\
\hline 3 & Komposisi warna & & & & \\
\hline 4 & Lay out & & & & \\
\hline \multicolumn{6}{|c|}{ Pendahuluan } \\
\hline 1 & Tata bahasa & & & & \\
\hline 2 & Penguatan latar belakang (teoritik/ fenomena) & & & & \\
\hline 3 & Dukungan data kuantitatif/ kualitatif & & & & \\
\hline 4 & Korelasi antar paragrap & & & & \\
\hline 5 & State of the art & & & & \\
\hline 6 & Closing & & & & \\
\hline \multicolumn{6}{|c|}{ Perumusan Tujuan/ Ruang Lingkup/ Pelaksanaan/ sumberdaya/ RAB } \\
\hline 1 & Kesesuaian dengan program grant & & & & \\
\hline 2 & Rasionalitas & & & & \\
\hline 4 & Tata bahasa & & & & \\
\hline 5 & Sistematika/ runtut & & & & \\
\hline
\end{tabular}

skor 1 =sangat tidak baik, 2 = tidak baik, 3 =baik dan $4=$ sangat baik

Peran fasilitator akan terlihat dalam perbaikan dan pengembangan hasil tulisan dan pengungkapan kekurangan program pelatihan hari kedua melalui evaluasi. Suasana diskusi yang hidup dan aktif menjadi sebuah tantangan tersendiri bagi fasilitator.

Metode penugasan mandiri dilakukan di kamar masing masing peserta pada sesi perbaikan tulisan usulan grant. Penugasan ini dimaksudkan untuk memperbaiki tulisan sesuai dengan materi dan arahan fasilitator. Perlu dibuat sebuah strategi agar peserta memiliki semangat untuk mengerjakan penugasan dengan baik. Sangat sering terjadi dalam sebuah pelatihan, ketika diberikan penugasan maka peserta tidak berkenan untuk mengerjakan ataupun jika mengerjakan namun dengan kondisi yang asal selesai.

\section{Indikator Keberhasilan Penyelenggaraan}

Indikator keberhasilan pelatihan secara umum adalah berupa peningkatan kemampuan menulis proposal grant dari peserta. Terdapat beberapa indikator yang dapat dilakukan penilaian keberhasilan pelatihan tersebut. Indikator pertama adalah cover, mampu memberikan informasi ringkas dan jelas serta menarik untuk dilihat. Indikator kedua adalah pendahuluan, bagaimana dalam pendahuluan ini mampu memberikan alasan yang kuat kenapa grant harus diberikan. Dukungan data kuantitatif maupun kualitatif yang kuat sangat diperlukan. Indikator ketiga adalah perumusan tujuan/ruang
lingkup/pelaksanaan/sumberdaya/RAB. Pada bagian ini sedapat mungkin mampu memberikan informasi eligibilitas terhadap grant yang ditawarkan, tepat dan masuk akal. Informasi yang dilebih-lebihkan adalah sesuatu yang wajib dihindari karena justru akan berakibat fatal.

Keberhasilan program pelatihan juga dapat dilihat bukan saja pada saat pelatihan namun juga impelementasi saat peserta kembali ke tempat kerja. Pemantaun dapat dilakukan dengan seberapa banyak grant/ kualitas grant yang diterima oleh penyuluh sendiri atau kelompok yang didampingi oleh penyuluh tersebut. Sebagaimana yang diungkapkan oleh Nikandrou, et al. (2009) bahwa implementasi hasil pelatihan selain dipengaruhi oleh kualitas pelatihan itu sendiri, juga oleh faktor-faktor dalam organisasi seperti reward, kultur, reputasi organisasi serta atmosfer organisasi dalam upaya mentransfer hasil pelatihan.

\section{KESIMPULAN DAN SARAN}

\section{Kesimpulan}

Tenaga THL-TB penyuluh pertanian didominasi oleh kelompok umur 31-40 tahun, dengan tingkat pendidikan SMA/sederajat serta masa kerja 10 tahun. Berdasarkan tabulasi silang kelompok umur dengan tingkat pendidikan tinggi (D3 dan sarjana) maka sasaran pelatihan penyusunan proposal grant bagi tenaga THLTB di Kabupaten Jember adalah sebanyak 48 
orang. Introduksi model rencana pelatihan penyusunan proposal grant menggunakan pendekatan Pimentel dan Franco (1991) yang terdiri atas perencanaan pelatihan terbagi 3 bagian besar, yaitu pra-implementasi, implementasi dan pasca implementasi.

\section{Saran}

Rencana peserta pelatihan harus dipilih secara obyektif sesuai dengan rujukan yaitu berusia kurang dari 40 dan berpendidikan tinggi (D3 atau Sarjana sarjana). Demikian pula pemateri dan fasilitator yang terlibat harus mengabaikan unsur kedekatan dan kepangkatan, serta memiliki kompetensi dan pengalaman penyusunan proposal grant. Kondisi paling krusial adalah pada sesi penugasan, pemateri/fasilitator harus benar-benar mampu membangun semangat peserta agar mau dan mampu mengerjakan tugas sesuai dengan rekomendasi yang diberikan.

\section{DAFTAR PUSTAKA}

Abubakar dan Siregar, A.N. 2010. Kualitas Pelayanan Penyuluh Pertanian Dan Kepuasan Petani Dalam Penanganan Dan Pengolahan Hasil Ubi Jalar (Ipomoea Batatas L.). Jurnal Penyuluhan Pertanian. 5(1), 1-15.

Adam, R.I. Sindi, K. Badstue, L. 2015. Farmers Knowledge, Perception and Management Disease Affecting Sweet Potato in The Lake Victoria Zone Region, Tanzania. Crop Protection. 72. 2015, 97-107.

Agunga, R. Cahyono, E.D. Buck, E dan Scheer, S. 2016. Challenges of Implementing Participatory Extension in Indonesia. Journal of Communication and Media Research. 8(1), 20-45.

Berry, M. 1993. Risk and Benefit of Open Adoption. The Future of Children. 3(1), 125-138.

Buadi, D.K. Anaman, K.A and Kwarteng, J.A. 2013. Farmers' Perceptions Of The Quality Of Extension Services Provided By Non-Governmental Organisations In Two Municipalities In The Central
Region Of Ghana. Agricultural Systems. 120 (2013),20-26.

Dickson, M. Nasr-Allah, A. Kenawy, D and Kruijssen, F. 2016. Increasing Fish Farm Profitability Through Aquaculture Best Management Practice Training In Egypt. Aquaculture. 465 (2016), 172-178.

Goad, T.W. (1982). Delivering Effective Training. San Diego, CA: Pfeiffer and Company.

Guo, M., et al. Jia. X. Huang, J. Kumar, K.B. Burger, N.E. 2015. Farmer field school and farmer knowledge acquisition in rice production: Experimental evaluation in China. Agric. Ecosyst. Environ. 2015. http://dx.doi.org/10.1016/j.agee.2015.02. 011.

Hashemi, S.M. Hosseini, S.M and Damalas. C.A. 2009. Farmers Competency and Training Needs on Pest Management Practices: Participation in Extension Worshop. Crop Protection. 28(2009), 934-939.

Huang, J. Huang, Z. Jia, X. Hu, R and Xiang, C. 2015. Long-Term Reduction Of Nitrogen Fertilizer Use Through Knowledge Training In Rice Production In China. Agricultural Systems 13. 2015, 105-111.

Nikandrou, I. Brinia, V and Bereri, E. 2009. Trainee Perception of Training Transfer: an Empirical Analysisi. Journal of European Industrial Training. 33(3), 255-270.

Orr, D and Mrazek, R. 2009. Developing The Level Of Adoption Survey To Inform Collaborative Discussion Regarding Educational Innovation. Canadian Journal of Learning and Technology. 35(2), 22-36.

Park, Y. Son, J. and Kim, C. 2012. Investigating the Determinants of Construction Professionals' Acceptance of Web-Based Training: An Extension of The Technology Acceptance Model. 
Automation in Construction. 22 (2012). 377-386.

Pimenetel and Franco, R. 1991. A how -to Book for Trainers and Teachers Training. National Book Store .INC, Metro Manila Philippines

Pitts, S.B.J. Mc Guirt, J.T. Wu, Q. 2016. Assessing Preliminary Impact of the North Carolina Community Transformation Grant Project Farmers' Market Initiatives Among Rural Residents. Journal of Nutrition Education and Behavior. 48(5), 343-349.

Raharto, S. 2016. Institutional Development Model Cocoa Farmers in East Java Province District Blitar. Agriculture and
Agricultural Science Procedia. 9 (2016), $95-102$.

Rozelle, S. Park, A. Benziger, V. 1998. Targeted Poverty Investments and Economic Growth in China. World Development. 26(12), 2137-2151.

Ton, G. Klerkx, L. De Grip, K. Rau, ML. 2015. Innovation grants to smallholder farmers: Revisiting the key assumptions in the impact pathways. Food Policy, 51(2015):9-23.

Westover, J.H. 2008. Effective Human Resource Training and Development: Examination and Application of Adult Learning Theory in the HR Management Context. The Journal of Human Resource and Adult Learning. 4(1), 1-8. 